\title{
SĖKMINGAS ORGANIZACINIŲ POKYČIŲ VALDYMAS
}

\author{
Karolina PETRAUSKAITE்*, Renata KORSAKIENE் \\ Vilniaus Gedimino technikos universitetas, Verslo vadybos fakultetas, Vadybos katedra, \\ Saulètekio al. 11, LT-10223, Vilnius, Lietuva \\ *El.paštas karolina.petrauskaite@stud.vgtu.lt
}

\begin{abstract}
Santrauka. Organizacijos nuolat susiduria su pokyčiais bei ju valdymu. Pokyčiu metu pasitaiko daug pasipriešinimo veiksnių bei didelè dalis pokyčiu igyvendinami nesẻkmingai. Šiame straipsnyje nagrinèjama organizacinių pokyčių samprata bei valdymo modeliai, identifikuojami organizacinių pokyčių valdymo sẻkmės veiksniai, atliekama požiūrių sėkmingo pokyčių valdymo klausimais lyginamoji analizè. Šios analizès pagrindu atliekamas ekspertų anketavimas, kuriuo siekiama identifikuoti sėkmès veiksnius taikomus organizacijose. Tyrimo metu nustatyta, kad svarbiausi sėkmès veiksniai, ekspertų nuomone, yra vizijos bei strategijos iškèlimas, tarpusavio komunikacija bei komandinis darbas.
\end{abstract}

Reikšminiai žodžiai: pokyčiai, pokyčių valdymas, organizaciniai pokyčiai, sėkmès veiksniai, organizacinių pokyčių valdymas, sèkmingas pokyčių valdymas.

\section{Ivadas}

Organizacijos veikia nuolat kintančioje aplinkoje. Didejjanti konkurencija, kintanti vartotojų paklausa ir reikalavimai, naujų technologijų atsiradimas, pasikeitimai organizacijos vidinèje aplinkoje, skatina organizacijas nuolat keistis bei atsinaujinti. Organizacijos, ignoruojančios pokyčius bei jų valdymo svarbą, gali ne tik prarasti konkurencines pozicijas rinkoje, bet ir žlugti. Nors didžioji dalis žmonių supranta, kad būtina reaguoti ị pokyčius, tačiau dar nedaugelis suvokia, kad pokyčius galima valdyti. Todèl tai tampa svarbia valdymo problema. Akivaizdu, kad pokyčiu valdymas nèra lengvas procesas, o pokyčiu būtinybès suvokimas dar negarantuoja jų ịgyvendinimo sẻkmès. Valdyti organizaciją įvedant naujus pokyčius nèra lengva, nes yra daug pasipriešinimo veiksnių su kuriais yra susiduriama pokyčiu metu. Norint išlikti rinkoje bei sẻkmingai konkuruoti su vietinėmis bei užsienio organizacijomis, svarbiausias aspektas - mokèjimas bei žinojimas kaip tinkamai valdymo pokyčius. Neapgalvotai vadovaujant ir ivvedant pokyčius galima prisidaryti daug žalos. Kad ir koki pokytị organizacijoje norima igyvendinti, susiduriama su baime, kad tas pokytis bus nesékmingas. Atsižvelgiant i tai, pokyčiu esmè, jų numatymas bei organizacijos gebejimas sèkmingai juos ịgyvendinti tampa aktualia ir vis plačiau tyrinëjama tema. Iš to kyla probleminis klausimas: Kokie yra sèkmės veiksniai organizaciniu pokyčių valdyme?

Tyrimo objektas: Organizacinių pokyčių valdymo sèkmès veiksniai.

Tikslas: Ištirti veiksnius, kurie ịgyvendintų sėkmingą pokyčių valdymą organizacijoje.

Tyrimo uždaviniai:

1. Atskleisti organizacinių pokyčių sampratą.

2. Išanalizuoti pokyčiu valdymo sèkmès veiksnius.

3. Atlikti ekspertų apklausą bei ịvertinti sėkmès veiksnius taikomus organizacijose.

Tyrimo metodai. Užsienio šalių ir lietuvių autorių mokslinès ir teorinès literatūros analizè, sisteminimas bei apibendrinimas, ekspertų apklausa.

\section{Organizacinių pokyčių samprata}

Mokslinèje literatūroje žodis „,pokytis“ analizuojamas gana plačiai. Pokyčio sąvoka gali būti apibrèžiama kaip tam tikras bet kokios srities pakitimas/permaina ar pakitimo/permainos rezultatas (Levovnik ir Gerbec, 2018). Remiantis Išoraite (2012), pokyčiai, tai - pakeitimai, kuriais siekiama tobulinti ar keisti organizacijos elementus. Šiuos pokyčius organizacijoje galima suskirstyti ị planuotus ir neplanuotus. Neplanuotos permainos dažniausiai ateina netikètai, todèl darbuotojai daug sunkiau bei negatyviau jas priima. Greiti ir netikèti pokyčiai beveik visada sukelia didelị darbuotojų pasipriešinimą. Darbuotojų pasipriešinimas vyksta dèl baimės, kad bus daugiau darbo, taip pat dèl nepasitikèjimo savo kompetencija, per mažo informacijos kiekio bei dèlto, kad darbuotojai nesupranta kam 
tie pokyčiai yra skirti. Tuo tarpu lètiems bei suplanuotiems pokyčiams darbuotojai priešinasi mažiau, lengviau juos priima. Pokyčių valdymas apibrèžiamas kaip gebejjimas prisitaikyti prie aplinkoje iškilusių iššūkių ar ịvykusių pasikeitimų. Kaip pastebi (Ali et al., 2019), jog gebejjimas valdyti organizacinius pokyčius yra laikomas ypač svarbiais vadybiniais ịgūdžiais ir pokyčių valdymas tampa neginčijama šiandienos valdymo užduotimi. Nagrinėjant organizacinių pokyčių sampratą, pastebima, jog daugumą autorių organizacinius pokyčius apibūdina kaip procesą (1 lentelè).

1 lentelè. Organizacinių pokyčių sąvoka (sudaryta autorès)

\begin{tabular}{|l|c|}
\hline \multicolumn{1}{|c|}{ Organizacinių pokyčių samprata } & \multicolumn{1}{c|}{ Autorius } \\
\hline $\begin{array}{l}\text { Procesas, kurio metu organizacija keičia savo tikslus, strategiją, struktūrą, } \\
\text { technologijas ar darbo metodus. }\end{array}$ & Holten ir Brenner (2015) \\
\hline $\begin{array}{l}\text { Procesas, kai įmonè pereina iš esamos būsenos ị kažkurią norimą būsimą } \\
\text { būseną. }\end{array}$ & $\begin{array}{c}\text { Al-Haddad ir Kotnour (2015), } \\
\text { Videikienė ir Šimanskienė (2013) }\end{array}$ \\
\hline $\begin{array}{l}\text { Stambūs pokyčiai vykstantys organizacijoje: misijos, vizijos pokyčiai, visiškas } \\
\text { organizacijos reorganizavimas, operacijų restruktūrizavimas, organizacijos } \\
\text { susiliejimas arba susiskaldymas, naujos technologijos ar naujos programos. }\end{array}$ & Lodienė (2005) \\
\hline Bet kokio pobūdžio pokyčiai vykstantys bendroje darbo aplinkoje. & Lewis (2011) \\
\hline $\begin{array}{l}\text { Būdas, kuriuo norima pasiekti organizacijos užsibrèžtų tikslų bei siekių, } \\
\text { tgyvendinti organizacijos viziją. }\end{array}$ & Arimavičiūtè ir Raišienė, (2015) \\
\hline
\end{tabular}

Išanalizavus mokslinę literatūrą, pastebima, kad lietuvių ir užsienių autorių nuomonès panašios bei papildo viena kitą. Autoriai organizacinius pokyčius ịvardina kaip procesą, kurio metu organizacija iš vienos būsenos pereina ị kitą, vykdo pokyčius bendroje darbo aplinkoje bei siekia ịgyvendinti organizacijos tikslus. Lodienė (2005) bei Al-Haddad ir Kotnour (2015) pabrèžia, kad organizaciniai pokyčiai, tai - stambūs pokyčiai ir kartais jie gali būti dideli ir dramatiški, pvz.: misijos, vizijos pokyčiai, visiškas organizacijos reorganizavimas, operacijų restruktūrizavimas, organizacijos susiliejimas arba susiskaldymas, naujos technologijos ar naujos programos.

Norint, kad organizacijoje pokyčiai vyktų sklandžiai, o darbuotojai be baimės priimtų permainas, Videikienė ir Šimanskienė (2013), pabrěžia, kad pokyčių valdymas pirmiausia turètų būti nukreiptas ị tai, kad padètų žmonėms prie jų prisitaikyti. Taigi, pokyčių valdymas gali būti apibrěžiamas kaip tikslingas procesas, organizuojant žmonių kolektyvą bei koordinuojant jų veiklą. Vis dèlto vykstant pokyčiams organizacijoje, dèmesys atkreipiamas ne tik $\mathfrak{i}$ darbuotojus, bet taip pat taikomos įvairios priemonès ir metodai siekiant pakeisti ar pagerinti organizacijos kultūros vertybes, žmogiškujų išteklių transformacijos procesą ir aplinką (Bold, 2011). Galima pastebėti, kad organizacinių pokyčių valdymas reikalauja veiksmingo vadovybès bei darbuotojų bendravimo. Norint išspręsti bet kokius rūpesčius vadovai turi užtikrinti, kad darbuotojai būtų nuolat mokomi bei nuolat jiems pabrež̌ti, kad vykstantys pokyčiai atitinka naujus įmonès tikslus.

Vis dèlto, nèra nustatyto vieno būdo, kuris sušvelnintų pokyčius, tačiau yra keli pokyčių valdymo modeliai, kuriais vadovaujasi organizacijos. Pokyčių valdymas nėra lengvas procesas ir ne visada duoda norimus rezultatus. Pasak Videikienè ir Šimanskienè (2014), taip yra todèl, kad nepakankamai atsižvelgiama i pokyčių valdymo etapų eiliškumą, praleidžiami tam tikri žingsniai, kurie sukelia iliuziją, kad vyksta pokyčiai, tačiau niekada negaunamas norimas rezultatas. Norint tinkamai suvokti kaip galima valdyti pokyčius, tikslinga apžvelgti kelis (iš daugelio) pokyčių valdymo modelius, t. y:

- Lewin modelis;

- Kotter modelis.

\section{Lewin modelis:}

Kurtas Levinas pokyčių valdymo strategiją sukūrè ketvirtajame dešimtmetyje, tačiau ji išlieka aktuali dèl paprastos, tačiau veiksmingos struktūros. Levino modelis susideda iš trijų pakopų: atšildymo, keitimosi ir užšaldymo (Nograšek, 2011). Autorius savo sukurtą modelį paaiškino paprasčiausiu pavyzdžiu, iškeldamas klausimą: kaip ledo kubą paversti ledo kūgiu (žr. 1 paveikslą).

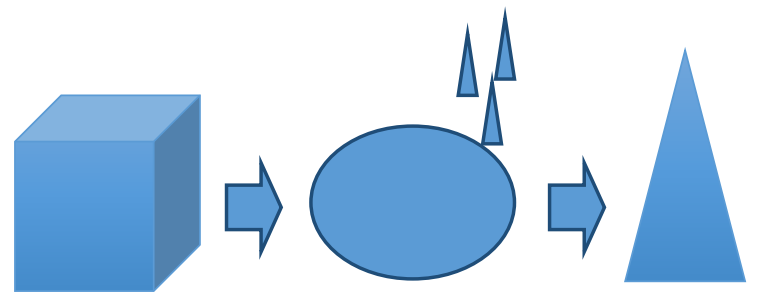

1 paveikslas. Kurto Levino pokyčių valdymo modelis (sudaryta autorès) 
Atšildymas: Pokyčiui tinkamo klimato kūrimas. Pirmasis ir pats svarbiausias etapas visame pokyčių valdyme. Remiantis Endrejat, Baumgarten ir Kauffeld (2017), atšildymo etapas skatina žmonių pasirengimą bei norą keistis, skatina pereiti iš komforto zonos i pasikeitusią situaciją. Pirmiausia komanda ar organizacija suvokia pokyčių poreikį, pamiršta esamą darbo procesą bei priima naujus darbo būdus, siekiant geresnių rezultatų (Jabri, 2017).

Keitimas: Visos organizacijos ịdarbinimas ir igalinimas. Pokyčių igyvendinimo etapas, kuris apima nauju darbo būdų prièmimą. Šiame etape keičiami darbo ịpročiai, priimami nauji sprendimai bei darbo atlikimo būdai. Pasak Burke (2017), labai svarbu ir būtina atidžiai planuoti veiksmus, nuolat bendrauti tarpusavyje, nes tai padeda komandai priartėti prie užduoties, siekiant vieno bendro tikslo.

Užšaldymas: Tobulinimas ir pokyčiu išlaikymas. İvykus pokyčiams, darbuotojai yra linkę grịžti prie senų ịpročių, todèl norint, kad pokyčiai nebūtų trumpalaikiai ir organizacijos darbuotojai negrịžtų i ankstesnę būseną, naują situaciją svarbu užšaldyti. Pasak (Jabri, 2017) užšaldymo etapas apima priimtų sprendimų sustiprinimą ir palaikymą. Taip pat užšaldymas stabilizuoja naują situaciją, suderinant skatinančias ir priešinimosi jègas.

Taigi, galima daryti išvadą, kad pagrindinè mintis, kurią turèjo omenyje Kurtas Levinas sudarydamas pokyčių valdymo modelį, buvo ta, kad labai dažnai pokyčių procese dalyvaujantys asmenys yra ignoruojami ir dèl to dauguma pokyčių žlunga. Kurtas Levinas pabrěžè pasiruošimą pokyčiams svarbą bei pokyčių sustiprinimo ir palaikymo poreikị po ịvykusių pasikeitimų.

\section{Kotter modelis:}

Per keturis dešimtmečius Koteris stebejjo daugybę lyderių ir organizacijų bandančių pertvarkyti ar igyvendinti savo strategijas. Kotter 8 žingsnių modelis kilo iš analizès daugiau kaip 100 įmonių, kurias jis konsultavo ir kurios išgyveno pokyčių procesą (Chebbi ir kt., 2019). Jo tyrimai išryškino aštuonias svarbiausias pamokas ir jis konvertavo tas žinias ị naudingą 8 žingsnių modelị (Lodienè, 2005) (žr. 2 paveikslą).

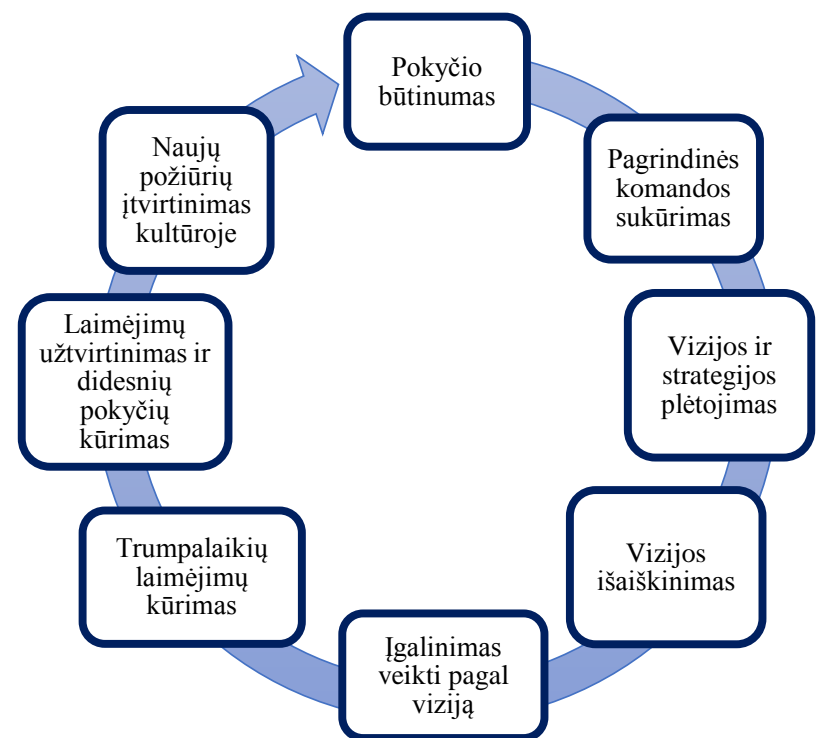

2 paveikslas. Kotter pokyčių valdymo modelis

Remiantis Tan, Gn ir Goh (2019), Wentworth, Behson ir Kelley (2018) bei Small et al. (2016) pateikiami paaiškinimai antrame paveiksle paminėtiems žingsniams.

Pokyčio būtinumas. Pirmame žingsnyje aktyviai analizuojamos supančios rinkos, diskutuojama apie potencialias krizes ar pasitaikančias galimybes.

Pagrindinès komandos sukürimas. Antrame žingsnyje surenkama organizacijos vadovų grupė, turinti pakankamai igaliojimų vadovauti pokyčiams.

Vizijos ir strategijos pletojimas. Trečiame žingsnyje sudaroma organizacijos vizija, kuri suteikia pokyčiams kryptingumą, suformuojamos strategijos tokios vizijos pasiekimui.

Vizijos išaiškinimas. Ketvirtame žingsnyje panaudojant visus galimus būdus ir priemones vizija ir strategijos perteikiamos organizacijai.

Igalinimas veikti pagal viziją. Penktame žingsnyje pašalinamos kliūtys pokyčiams ir pakeičiančios neatitinkančios sistemos.

Trumpalaikiu laimẹjimu kūrimas. Šeštame žingsnyje suplanuojami aiškiai matomi ir per trumpą laiką pasiekiami veiklos pagerinimai, jie realizuojami.

Laimejimu užtvirtinimas ir didesniu pokyčiu kūrimas. Septintame žingsnyje nuolat vertinama ir atsisakoma pokyčių realizavimo būdų, struktūrų ir procedūrų, nesiderinančių su vizija. 
Nauju požiūriu ịtvirtinimas kultūroje. Aštuntame žingsnyje nustatomas ryšys tarp naujų veikimo būdų ir organizacijos sėkmės bei sukuriamos priemonès, užtikrinančios tolimesnị vystymą ir sėkmingą veiklą.

Taigi, išnagrinėjus Kotter 8 žingsnių modeli pastebèta, kad autorius didelị dèmesị skiria pokyčio būtinumo išaiškinimui, komandos ir vizijos kūrimui, tarpusavio komunikacijai ir bendrai veiklai bei svarbą pokyčių ịtvirtinimui. Taip pat galima pastebėti, kad Kotter ir Lewin modeliai turi tarpusavio sąsajų bei papildo vienas kitą. Keturi pirmi Koterio žingsniai (būtinumo jausmo sukūrimas, pagrindinès komandos sukūrimas, vizijos plètojimas, komunikacija) gali būti priskiriami prie Levino atšildymo etapo. Penktas ir šeštas Koterio žingsnis (darbuotojų igalinimas veiksmui, trumpalaikių laimèjimų kūrimas) gali būti priskirti prie Levino keitimo etapo. Septintas ir aštuntas žingsnis (didesnių pokyčių kūrimas, pokyčių ịtvirtinimas), gali būti priskirti prie užšaldymo etapo.

Apibendrintai galima teigti, kad organizaciniai pokyčiai, tai procesas, kurio metu organizacija pereina iš vienos būsenos ị kitą: keičia savo tikslus, viziją, strategiją, darbo metodus ar ịveda naujas programas bei technologijas. Tai nuolat besikeičiantis procesas, kuris paveikia visus organizacijos dalyvius, todèl labai svarbu efektyviai vadovauti bei užtikrinti vadovybès ir darbuotojų tarpusavio komunikaciją. Valdant pokyčius organizacijose, labai svarbu atsižvelgti ị etapų eiliškumą bei nepraleisti nei vieno žingsnio. Taip pat svarbu tinkamai pasiruošti pokyčiams, t. y. išsiaiškinti pokyčių būtinumą bei svarbą, suburti komandą, išsikelti viziją, nuolat dirbti ir komunikuoti tarpusavyje bei sustiprinti ir įtvirtinti įvykusius pokyčius. Laikantis pokyčių valdymo eiliškumo, galima užtikrinti sėkmingą pokyčių valdymą organizacijose.

\section{Organizacinių pokyčių valdymo sèkmès veiksniai}

Igyvendinant pokyčius, susiduriama su ịvairiomis kliūtimis, darbuotojų pasipriešinimu, finansiniais sunkumais, nenoru keisti iprastą tvarką ir pan. (Videikienė ir Šimanskienė, 2013). Manoma, kad dažniausios nepritarimų pokyčiams priežastys: pokyčių nesupratimas, baimè prarasti statusą, baimė prarasti galią, nepasitikejjimas savo kompetencija, darbo masto didinimas (Vienažindienė ir Čiarnienė, 2007). Atsižvelgiant ị tai, labai svarbu analizuoti pokyčių ịgyvendinimo sėkmès veiksnius bei ịvairių autorių apibrèžtus sėkmingo pokyčių ígyvendinimo ir valdymo žingsnius ar etapus. Autorių nuomonių palyginamoji analizė pateikta 2 lentelèje.

2 lentelè. Organizacinių pokyčiu valdymo sèkmès veiksniai (sudaryta autorès)

\begin{tabular}{|l|c|c|c|c|c|}
\hline & $\begin{array}{c}\text { Hussain } \\
\text { et al. (2018) }\end{array}$ & $\begin{array}{c}\text { Pollack ir } \\
\text { Pollack (2015) }\end{array}$ & $\begin{array}{c}\text { Al-Haddad ir } \\
\text { Kotnour (2015) }\end{array}$ & $\begin{array}{c}\text { Cameron ir } \\
\text { Green (2015) }\end{array}$ & $\begin{array}{c}\text { Petrou, Demerouti } \\
\text { ir Schaufeli (2018) }\end{array}$ \\
\hline Lyderyste & $\mathrm{X}$ & & $\mathrm{X}$ & $\mathrm{X}$ & $\mathrm{X}$ \\
\hline Komandinis darbas & $\mathrm{X}$ & $\mathrm{X}$ & & $\mathrm{X}$ & $\mathrm{X}$ \\
\hline Vizijos ir strategijos iškèlimas & & $\mathrm{X}$ & $\mathrm{X}$ & & $\mathrm{X}$ \\
\hline Pokyčių būtinumo nustatymas & & $\mathrm{X}$ & & & \\
\hline Pokyčių ìtvirtinimas & & $\mathrm{X}$ & & & \\
\hline Tarpusavio komunikacija & $\mathrm{X}$ & $\mathrm{X}$ & $\mathrm{X}$ & $\mathrm{X}$ & \\
\hline Smulkių rezultatų akcentavimas & & $\mathrm{X}$ & $\mathrm{X}$ & & $\mathrm{X}$ \\
\hline
\end{tabular}

Palyginus autorių nuomones, matoma, kad autoriai išskiria penkis veiksnius užtikrinančius sèkmingą pokyčių valdymą organizacijoje, t. y. lyderyste, komandinis darbas, vizijos ir strategijos iškèlimas, tarpusavio komunikacija ir smulkių rezultatų akcentavimas. Pasak Hussain et al. (2018), lyderyste yra vienas iš svarbiausių veiksnių norint užtikrinti sėkmingą pokyčių valdymą organizacijoje. Vadovas vaidina gyvybiškai svarbų vaidmenị renkantis ir planuojant racionalų organizacijos pokyčių valdymą, todèl lyderiams svarbu teisingai suprasti organizacijos pokyčius ir sukurti saugią bei tinkamą aplinką, kuri padètų darbuotojams dalyvauti pokyčiuose (Ajmal et al., 2012). Galima daryti prielaidą, jog organizacijos vadovas turètų ugdyti lyderio savybes, nes jo asmeniniai sugebejjimai, pasirengimas, žinios ir patirtis galètų garantuoti sẻkmingą bei efektyvų pokyčių valdymą organizacijoje. Pasak Ganta ir Manukonda (2012), efektyviai dirbantis vadovas yra tas, kuris sugeba suvaldyti pasipriešinimą ir sėkmingai igyvendinti pokyčius. Vadovas privalo informuoti ir ịtikinti darbuotojus dèl pokyčių neišvengiamumo, identifikuoti bei sugebèti prisiimti reikiamo laipsnio riziką, ịvertinti jos ịveikimo būdus ir priemones bei sugebèti prisitaikyti prie naujų aplinkybių (Videikienè ir Šimanskienė, 2013). Konferencijoje „Pokyčių evoliucija: keiskis arba mirk“, „Change Partners“ pokyčių konsultantè Lina Mieliauskienė pabrèžè, kad pokyčiai organizacijoje prasideda tada, kai i pokyčius įsitraukia kiekvienas darbuotojas. Sudaroma prielaida, kad vadovas kaip lyderis privalo teisingai susidėlioti prioritetus bei ị pokyčius įtraukti visą komandą, kadangi organizacijoje yra siekiama vieno bendro rezultato.

Kitas labai svarbus veiksnys užtikrinantis sėkmingą pokyčių valdymą organizacijoje - komunikacija. Vadovo ir darbuotojų tarpusavio komunikacija padeda darbuotojams suvokti pokyčių poreikị bei jų asmeninę įtaką jiems (Videikienė ir Šimanskienè, 2013). Komunikuojant svarbu suprasti kiekvieno darbuotojo vertybes bei pokyčiu 
suvokimą. Pasak organizacijų psichologų, Lietuvos darbo rinkoje šiuo metu dominuoja dvi kartos, t. y. „X“ karta (gimę 1965-1980 metai) ir „,Y“ karta (1980-2000 metų gimimo). Prognozuojama, kad jau 2020-aisiais „Y“ karta sudarys apie 40 proc. visos darbo jëgos, todèl reikètų galvoti apie dvi skirtingas pokyčių žinias dviem pagrindinėms kartoms. Remiantis Levickaitė (2010), „X“ karta perèmè savo tėvų vertybes - modernizmą, stabilumą, šeimą, karjerą, aiškumą, identitetą, pagarbą elitui ir autoritetui, o „Y“ kartai svarbu globalumas ir individualumas, mobilumas ir technologijos, ji pamišusi dèl savo įvaizdžio, hobio ir kelionių, siekia malonumo ir neprisiriša nei prie tikslų, nei prie darbo vietos, nei prie žmonių.

Sèkmingą pokyčių valdymą organizacijose taip pat apibūdina anksčiau paminètas Kotter 8 žingsnių modelis, kuriame autorius skyrè didelį dèmesị komandiniam darbui, vizijos kūrimui bei vèlgi komunikacijai.

Taigi, apibendrinus, galima daryti prielaidą, kad sėkmingas organizacinių pokyčių valdymas priklauso nuo lyderystès, komandinio darbo, nuolatinès vadovo ir darbuotojų komunikacijos, vizijos bei strategijos iškèlimo ir smulkių rezultatų akcentavimo. Taip pat vadovams arba kitaip tariant lyderiams svarbu labai gerai suprasti pokyčius ir jų svarbą, informuoti ir įtikinti darbuotojus dèl pokyčių neišvengiamumo, motyvuoti bei i pokyčius ịtraukti visą komandą, kadangi organizacijoje yra siekiama vieno bendro rezultato.

\section{Tyrimo metodologija}

Išanalizavus mokslinę literatūrą bei atlikus lietuvių ir užsienio autorių palyginamąją analizę, buvo išskirti penki veiksniai lemiantys sẻkmingą pokyčių valdymą: lyderystė, komunikacija, komandinis darbas, vizijos ir strategijos iškèlimas bei smulkių rezultatų akcentavimas. Tyrimo metu buvo atliktas ekspertu anketavimas, siekiant išanalizuoti pokyčiu valdymo sékmès veiksnius taikomus organizacijoje bei suprasti, kurie veiksniai, ekspertu nuomonę yra svarbiausi pokyčiu valdyme. Tyrimas buvo suskirstytas ị keturis etapus (žr. 3 paveikslą).

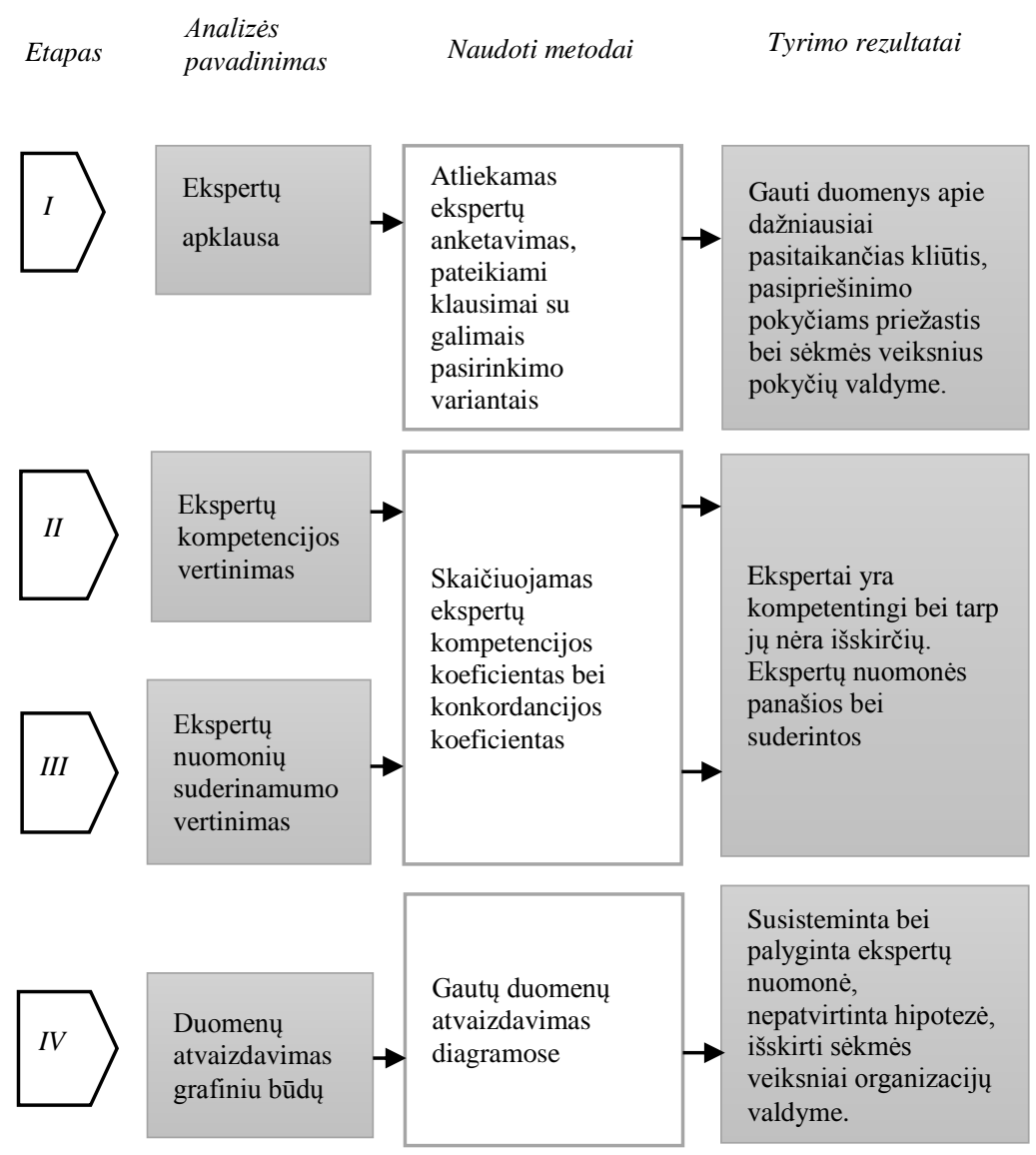

3 paveikslas. Sèkmės veiksnių tyrimo etapai (sudaryta autorès)

Pirmas etapas: Tyrimui atlikti buvo apklausti penki ekspertai, kurių darbo patirtis yra ne mažesnè nei pusè metų. Ekspertams buvo išdalintos anketos su pateiktais galimais atsakymų variantais. Apklausus ekspertus buvo surinkti duomenys apie dažniausiai pasitaikančias pasipriešinimo pokyčiams kliūtis, pasipriešinimo priežastis bei sèkmès veiksnius pokyčių valdyme. 
Antras etapas: Apskaičiuotas ekspertų kompetencijos koeficientas. Nustatyta, kad ekspertai yra kompetentingi, tarp jų nèra išskirčių ir gauti duomenys gali būti naudojami tolimesniam tyrimui.

Trečias etapas: Apskaičiuotas konkordancijos koeficientas. Nustatyta, kad ekspertų nuomonès yra panašios bei suderintos.

Ketvirtas etapas: Tyrimo rezultatai pavaizduoti diagramose, susistemintos ir palygintos ekspertų nuomonès. Paneigta iškelta hipotezè ir išskirti sėkmės veiksniai organizacinių valdyme.

\section{Ekspertų kompetencijos ir nuomonių suderinamumo vertinimas}

Vertinant ekspertų kompetenciją ir nuomonių suderinamumą, visų pirma ekspertų ịverčiai yra paverčiami rangais. Didžiausiam ekspertų ịverčiui (5) suteikiamas 1 rangas, sekančiam ekspertų įverčiui (4) suteikiamas 2 rangas ir t. t. Lentelè su rangais pateikta 2 priede.

Ekspertų kompetencijos koeficientu apskaičiavimas. Kompetencijos koeficientai parodo ar tarp apklaustujų yra ekspertų, kurių vertinimai gali būti laikomi išskirtimis. Norint ịsitikinti ar apklaustieji ekspertai yra kompetentingi ir ar nėra išskirčių - visi apskaičiuotieji kompetencijos koeficientai turi patekti i intervalą $K_{i}^{t}-1.96 s \leq K_{i}^{t}+1.96 s$, kur $K_{i}^{t}$ - kompetencijos koeficientų vidurkis, o $s$-standartinis nuokrypis.

Panaudojus kendall metodą, buvo apskaičiuoti visų ekspertų kompetencijos koeficientai bei atitinkamas intervalas ị kurị turètų ịeiti visi gautieji koeficientai. Gautieji duomenys pateikti 3 lentelejje, o skaičiavimai pateikti 2 priede.

3 lentelè. Ekspertų kompetencijos koeficientai (sudaryta autorès)

\begin{tabular}{|c|c|c|}
\hline & Kompetencijos koeficientas & Intervalas \\
\hline E1 & 0,205 & \\
\hline E2 & 0,200 & \multirow{2}{*}[0,194;0,206]{} \\
\hline E3 & 0,200 & \\
\hline E4 & 0,197 & \\
\hline E5 & 0,198 & \\
\hline
\end{tabular}

Iš ketvirtos lentelès matyti, kad apskaičiuotasis intervalas, ị kurị turètų įeiti visų ekspertų kompetencijos koeficientai, yra [0,194;0,206]. Taip pat pastebima, kad pirmojo eksperto (E1) kompetencijos koeficientas siekia 0,205, antrojo ir trečiojo eksperto (E2 ir E3) kompetencijos koeficientai yra 0,200, ketvirtojo eksperto $(E 4)$ - 0,197 ir penktojo eksperto (E5) kompetencijos koeficientas siekia 0,198. Taigi, pastebima, kad visi apskaičiuotieji ekspertų koeficientai įeina ị intervalą [0,194;0,206], vadinasi daroma išvada, kad ekspertai yra kompetentingi ir jų vertinimai gali būti naudojami tyrimui.

Konkordancijos koeficiento skaičiavimas. Norint nustatyti ar apklaustų ekspertų nuomonès yra suderinamos, skaičiuojamas konkordancijos koeficientas (W). Prieš pradedant skaičiuoti konkordancijos koeficientą, iškeliamos dvi hipotezès:

$\mathrm{W}=0$, ekspertų vertinimai prieštaringi;

$\mathrm{W} \neq 0$, ekspertų vertinimai panašūs.

Konkordancijos koeficientas apskaičiuojamas pagal formulę:

$$
W=\frac{12 S^{2}}{m^{2}\left(k^{3}-k\right)-m T},
$$

čia: $w$ - konkordancijos koeficientas; $m$ - ekspertų skaičius; $k$ - veiksnių skaičius; $S^{2}$ - nuokrypio nuo rangų sumos vidurkio kvadratų suma.

Apskaičiavus gaunama, kad S${ }^{2}=122$ (skaičiavimai pateikti 3 priede). Apskaičiavus $\mathrm{S}^{2}$, tikslinga paskaičiuoti maksimalią galima nuokrypio kvadratų sumą $\left(\mathrm{S}^{2}{ }_{\max }\right)$. Jeigu gautoji nuokrypio kvadratų sumą $\left(\mathrm{S}^{2}\right)$ didesné už maksimalią nuokrypio kvadratų sumą $\left(\mathrm{S}^{2}{ }_{\max }\right)$, toliau tyrimo tęsti negalima. Maksimali nuokrypio nuo rangų sumos vidurkio kvadratų suma apskaičiuojama pagal formulę:

$$
S_{\max }^{2}=\frac{m^{2}\left(k^{3}-k\right)-m \sum_{i=1}^{r} T_{l}}{12},
$$

čia: $S^{2}{ }_{\max }$ - maksimali rangų sumos vidurkio kvadratų suma; $m$ - ekspertų skaičius; $k$ - veiksnių skaičius.

$$
S_{\max }^{2}=\frac{25 \cdot(125-5)}{12}=250 \text {. }
$$


Kadangi gauti rezultatai parodo, kad $S^{2}<S^{2}{ }_{\max }$, t. y. $122<250$, vadinasi galima tęsti tyrimą bei apskaičiuoti konkordancijos koeficientą.

Konkordancijos koeficientas apskaičiuojamas pagal (1) formulę:

$$
W=\frac{12 \cdot 122}{25 \cdot(125-5)}=0,5 \text {. }
$$

Taigi, apskaičiuotas konkordancijos koeficientas (W) lygus 0,5. Galima teigti, kad ekspertų nuomonės yra suderintos, nes konkordancijos koeficientas yra didesnis už 0 , t. y. nulinè hipotezè $(\mathrm{W}=0)$ atmetama. Vis dèlto tikslinga būtų pasitikrinti ar gautasis konkordancijos koeficientas nèra atsitiktinè reikšmè. Skaičiuojama faktinė $\chi^{2}$ skirstinio reikšmè, pagal formulę:

$$
\chi^{2}=W m(k-1),
$$

čia: $\chi^{2}$ - faktinè skirstinio reikšmė; $w$ - konkordancijos koeficientas; $m$ - ekspertų skaičius; $k$ - veiksnių skaičius.

$$
\chi^{2}=0,5 \cdot 5 \cdot(5-1)=10 .
$$

Faktinė $\chi^{2}$ skirstinio reikšmė turètų būti palyginta su kritine $\chi^{2}(0,05 ; \mathrm{k}-1)$ reikšme. Jeigu faktinė reikšmė yra didesnė už kritinę reikšmę, vadinasi apskaičiuotas konkordancijos koeficientas nèra atsitiktinai gautas dydis. Kritinė $\chi^{2}$ reikšmė yra randama statistinejje lentelèje intervale $(0,05 ; 4)$ šiuo atveju $\chi^{2}=9,48$. Taigi, matoma, kad faktinè reikšmė yra didesnè už kritinę reikšme, t. y. $10>9,48$, vadinasi gautas konkordancijos koeficientas nėra tik atsitiktinai gauta reikšmė bei ekspertų nuomonès yra suderintos.

Apibendrinus galima teigti, kad tarp apklaustų ekspertų nėra išskirčių ir visi ekspertai yra kompetentingi atlikti sẻkmès veiksnių pokyčių valdyme vertinimą, kadangi gautieji ekspertų kompetencijos koeficientai įeiną i apskaičiuotą intervalą. Taip pat apskaičiavus konkordancijos koeficientą ir patikrinus ar tai nèra tik atsitiktinai gauta reikšmė, nustatyta, kad apklaustų ekspertų nuomonės suderinamos, t. y. ekspertų vertinimai yra panašūs.

\section{Organizacinių pokyčių valdymo sèkmès veiksnių tyrimo rezultatai}

Tyrimui atlikti buvo apklausti 5 ekspertai dirbantys Lietuvos įmonėse bei kurių darbo patirtis yra ne mažesnė nei pusè metų. Ekspertams buvo pateiktos anketinès apklausos su galimais pasirinkimo variantais (1 priedas).

Pirmuoju klausimu buvo siekiama išsiaiškinti, kaip ekspertai supranta organizacinius pokyčius įmonèje, t. y. kaip jų nuomone galètų būti apibrèžiama organizacinių pokyčių sąvoka. Rezultatai pateikti 4 paveiksle.

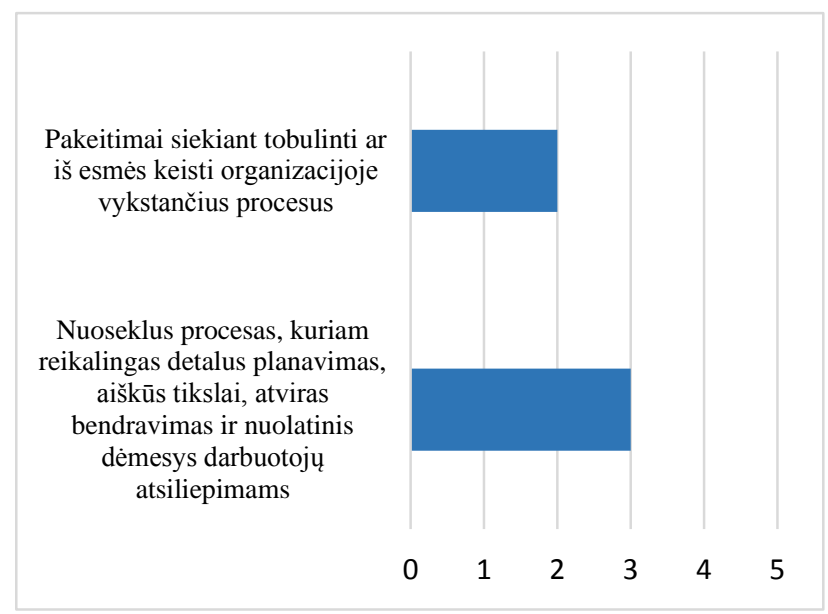

4 paveikslas. Organicazinių pokyčių sąvoką - ekspertų vertinimas (sudaryta autorès)

Ekspertai pritare pateiktiems variantams ir kaip matyti iš ketvirto paveikslo, didžioji dalis ekspertų (3 ekspertai iš 5) organizacinių pokyčių sąvoką apibrezžia kaip nuoseklų procesą, kuriam reikalingas detalus planavimas, aiškiai iškelti tikslai, atviras tarpusavio bendravimas bei nuolatinis dèmesys darbuotojų atsiliepimams. Taip pat dalis ekspertų (2 ekspertai iš 5) organizacinius pokyčius įvardino kaip pakeitimus įmoneje, kuriais siekiama patobulinti ar iš esmès pakeisti organizacijoje vykstančius procesus. Pateikti apibrezžimai iš esmès yra panašūs bei vienas kitą papildo, tiek vienas, tiek kitas apibrèžimas yra laikomas teisingu, todèl visų ekspertų pasirinkimai yra priimtini. 
Taip pat ekspertų buvo paklausta ar jie yra susidūrę su pokyčiais organizacijose, visi ekspertai atsakè, kad taip. Iš to kilo klausimas - su kokios kliūtimis teko susidurti valdant pokyčius organizacijoje. Gauti duomenys pateikti 5 paveiksle.

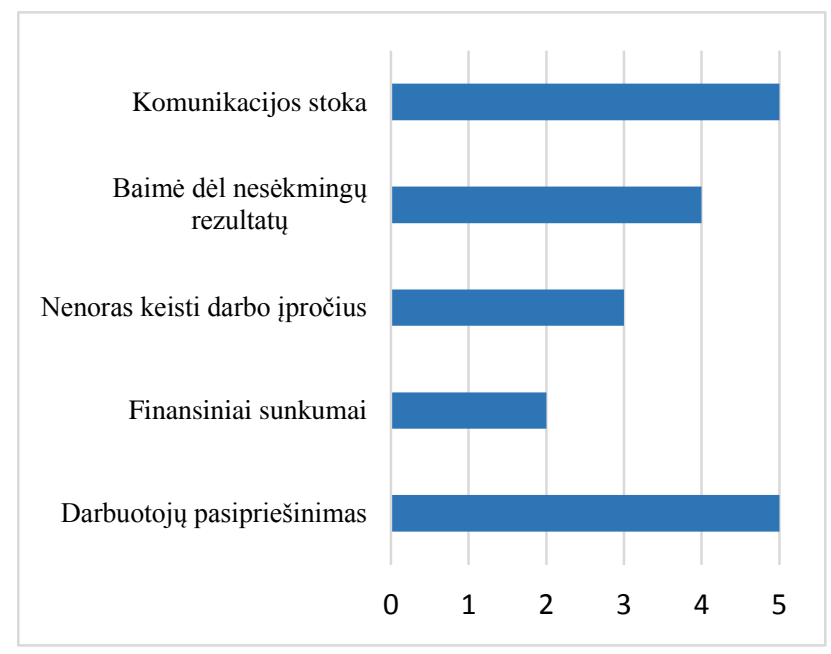

5 paveikslas. Dažniausiai pasitaikančios kliūtys organizacinių pokyčių valdyme (sudaryta autorès)

Iš penktame paveiksle pateiktų duomenų matyti, kad valdant pokyčius organizacijoje, dažniausiai susiduriama su komunikacijos stoka bei darbuotojų pasipriešinimu. Šiuos du veiksnius įvardino visi penki ekspertai. Taip pat keturi iš penkių ekspertų ịvardino, kad pokyčius sunku valdyti dėl baimès, jog rezultatai bus nesėkmingi. Trys iš penkių ekspertų ịvardino, kad nenoras keisti darbo ịpročius taip pat turi ịtakos pokyčių valdyme.

Kadangi visi ekspertai pažymėjo, jog valdant pokyčius organizacijoje, dažnai susiduria su darbuotojų pasipriešinimu, ekspertų buvo paklausta, kaip jie mano dèl kokių priežasčių darbuotojai priešinasi. Gautieji rezultatai pateikti 6 paveiksle.

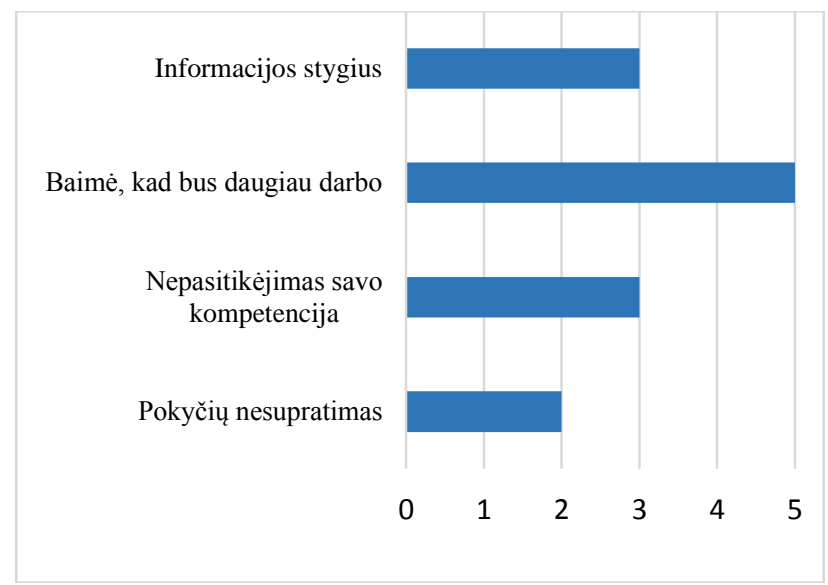

6 paveikslas. Priežastys, dèl kurių, ekspertų nuomone, darbuotojai priešinasi pokyčiams (sudaryta autorès)

Iš šešto paveikslo duomenų matoma, kad ekspertų nuomone darbuotojai pokyčiams priešinasi dẻl baimės, jog bus daug darbo. Taip pat dauguma ekspertų pažymèjo, kad darbuotojai priešinasi pokyčiams, nes gauna per mažai informacijos dèl vykstančių ar norimų vykdyti pokyčių bei nepasitikëjimo savo kompetencija. Du iš penkių ekspertų mano, kad darbuotojai priešinasi pokyčiams dèlto, kad visiškai nesupranta pokyčių bei su svarbos.

Ekspertų buvo paprašyta ịvertinti nuo 1 iki 5 veiksnius, kurie labiausiai jų nuomone lemia sẻkmingą pokyčių valdymą įmonèje. Svarbiausiam kriterijui buvo priskirta didžiausia reikšmè (5), o mažiausiai svarbiam kriterijui mažiausia reikšmė (1). Gauti duomenys pateikti 3 lentelèje.

Iš trečios lentelès matyti, kad didžioji dalis ekspertų, vizijos ir strategijos iškèlimą laiko vienu svarbiausių veiksnių organizacinių pokyčių valdyme, šiam kriterijui dauguma ekspertų skyrè 5 balus. Komunikaciją bei komandinị darbą ekspertai taip pat vertina svarbiais sėkmès veiksniais, kadangi šiems kriterijams daugiausiai skyrè po 2 arba 3 balus. Mažiausiai svarbus kriterijus pokyčių valdyme ekspertų nuomone yra lyderio vaidmuo, šiam kriterijui dauguma ekspertų skyrè 1 balą. 
4 lentelè. Organizacinių pokyčių valdymo sėkmès veiksnių svarbos ekspertinis įvertinimas (nuo 1 iki 5) (sudaryta autorès)

\begin{tabular}{|c|c|c|c|c|c|}
\hline & \multicolumn{5}{|c|}{ Veiksniai } \\
\hline $\begin{array}{c}\text { Eksperto } \\
\text { numeris }\end{array}$ & $\begin{array}{c}\text { Lyderio } \\
\text { vaidmuo }\end{array}$ & Komunikacija & $\begin{array}{c}\text { Vizijos ir strategijos } \\
\text { iškèlimas }\end{array}$ & $\begin{array}{c}\text { Komandinis } \\
\text { darbas }\end{array}$ & $\begin{array}{c}\text { Smulkiu rezultatu } \\
\text { akcentavimas }\end{array}$ \\
\hline$E 1$ & 1 & 4 & 5 & 3 & 2 \\
\hline$E 2$ & 4 & 2 & 5 & 3 & 1 \\
\hline$E 3$ & 4 & 3 & 5 & 2 & 1 \\
\hline$E 4$ & 1 & 3 & 5 & 2 & 2 \\
\hline$E 5$ & 1 & 3 & 4 & 5 & 2 \\
\hline
\end{tabular}

Taigi, apibendrinus tyrimo rezultatus, galima daryti išvada, kad visi apklaustieji ekspertai organizacinius pokyčius supranta labai panašiai, jie įvardino, kad tai pakeitimai siekiant patobulinti procesus organizacijoje bei taip pat ịvardino, kad tai nuoseklus procesas, kuriam reikalingas detalus planavimas, aiškūs tikslai, nuolatinis tarpusavio bendravimas bei dėmesys darbuotojų atsiliepimams. Visi ekspertai yra susidūrę su pokyčiais bei jų valdymu organizacijoje. Dauguma jų ịvardino, kad dažniausiai pasitaikančios kliūtys valdant pokyčius, tai - komunikacijos stoka bei darbuotojų pasipriešinimas arba baimè, jog galutinis rezultatas bus nesèkmingas. Taip pat ekspertų paklausus kaip jie mano, dèl kokių priežasčių darbuotojai priešinasi pokyčiams - atsakè, kad dažniausiai darbuotojai priešinasi, kad ịvykus pokyčiams bus daugiau darbo, taip pat dèl per mažo kiekio informacijos apie pokyčius bei dẻl nepasitikèjimo savo kompetencija. Ekspertų nuomone sėkmingas organizacinių pokyčių valdymas labiausiai priklauso nuo vizijos bei strategijos iškèlimo, taip pat nuo tarpusavio komunikacijos ir komandinio darbo.

\section{Išvados}

1. Organizacinių pokyčių valdymas gali būti apibréžiamas kaip nuoseklus procesas, kuriam tai procesas, kurio metu organizacija pereina iš esamos būsenos ị kitą: keičia savo tikslus, viziją, strategiją, darbo metodus ar ịveda naujas programas bei technologijas. Tai nuolat besikeičiantis procesas, kuris paveikia visus organizacijos dalyvius, todèl labai svarbu efektyviai vadovauti ir stiprinti pastangas keistis.

2. Palyginus autorių nuomones, prieita išvada, kad sèkmingas organizacinių pokyčių valdymas priklauso nuo lyderystės, komandinio darbo, nuolatinès vadovo ir darbuotojų komunikacijos, vizijos bei strategijos iškèlimo ir smulkių rezultatų akcentavimo.

3. Apklausus ekspertus bei atliktus sėkmès veiksnių tyrimą organizacijose, nustatyta, kad sėkmingą pokyčių valdymą, ekspertų nuomone, organizacijoje labiausiai lemia trys veiksniai: vizijos ir strategijos iškèlimas, tarpusavio komunikacija bei komandinis darbas.

\section{Literatūra}

Ajmal, S., Farooq, M. Z., Sajid, N., \& Awan, D. S. (2012). Role of leadership in change management process. Abasyn Journal of Social Sciences, 5(2), 111.

Al-Haddad, S., \& Kotnour, T. (2015). Integrating the organizational change literature: A model for successful change. Journal of Organizational Change Management, 28(2), 234-262. https://doi.org/10.1108/JOCM-11-2013-0215

Ali, H. M. Al, Ajmal, M. M., Gunasekaran, A., \& Helo, P. T. (2019). Managing change in constant evolving sustainable energy market: An exploratory study of motivators, enablers, and barriers. Sustainable Production and Consumption, 20, 84-97. https://doi.org/10.1016/j.spc.2019.05.005

Arimaviciute, M., \& Raisiene, A. G. (2015). Model for management of strategic changes and its application in municipalities of Lithuania. Journal of International Studies, 8(3), 78-89.

Bold, E. (2011). Instruments and techniques used in the design and implementation of change management. Journal of Advanced Research in Management, 1, 4-17.

Burke, W. W. (2017). Organization change - Theory and practice. SAGE Publications.

Cameron, E., \& Green, M. (2015). Making sense of change management: A complete guide to the models, tools and techniques of organizational change $\left(4^{\text {th }}\right.$ ed.). Kogan Page.

Chebbi, H., Yahiaoui, D., Sellami, M., Papasolomou, I., \& Melanthiou, Y. (2019). Focusing on internal stakeholders to enable the implementation of organizational change towards corporate entrepreneurship: A case study from France. Journal of Business Research (in Press). https://doi.org/10.1016/j.jbusres.2019.06.003

Endrejat, P. C., Baumgarten, F., \& Kauffeld, S. (2017). When Theory meets practice: Combining Lewin's ideas about change with motivational interviewing to increase energy-saving behaviours within organizations. Journal of Change Management, 17(2), 101-120. https://doi.org/10.1080/14697017.2017.1299372

Ganta, V. Ch., \& Manukonda, J. K. (2012). Leading the change in organizations. International Journal of Research in IT and Management (IJRIM), 7(1), 73-81. http://euroasiapub.org/wp-content/uploads/2017/03/10IMJan-6020irjms.pdf 
Holten, A.-L., \& Brenner, S. O. (2015). Leadership style and the process of organizational change. Leadership \& Organization Development Journal, 36(1), 2-16. https://doi.org/10.1108/LODJ-11-2012-0155

Hussain, S. T., Lei, S., Akram, T., Haider, M. J., Hussain, S. H., \& Ali, M. (2018). Kurt Lewin's change model: A critical review of the role of leadership and employee involvement in organizational change. Journal of Innovation \& Knowledge, 3(3), 123-127. https://doi.org/10.1016/j.jik.2016.07.002

Išoraite, M. (2012). Teoriniai strateginių pokyčiu aspektai. Verslo Sistemos ir Ekonomika - Business Systems \& Economics, 2(2), 130-145. https://repository.mruni.eu/bitstream/handle/007/13227/276-489-1-PB.pdf?sequence=1\&isAllowed=y

Jabri, M. (2017). Managing Organizational change-Process, social construction and dialogue (2 ${ }^{\text {nd }}$ ed.). Red Globe Press.

Levickaitè, R. (2010). Y, X, Z kartos: pasaulio be sienų idèjos formavimas naudojantis socialiniais tinklais (Lietuvos ateitis). Creativity Studies, 3(2), 170-183. https://doi.org/10.3846/limes.2010.17

Levovnik, D., \& Gerbec, M. (2018). Operational readiness for the integrated management of changes in the industrial organizations - Assessment approach and results. Safety Science, 107, 119-129. https://doi.org/10.1016/j.ssci.2018.04.006

Lewis, L. K. (2011). Organizational change: Creating change through strategic communication. organizational change: creating change through strategic communication. Wiley. https://doi.org/10.1002/9781444340372

Lodienė, D. (2005). Pokyčių samprata ir jų valdymo suvokimas. Organizacijų vadyba: sisteminiai tyrimai, 33, 99-109. https://etalpykla.lituanistikadb.lt/fedora/objects/LT-LDB0001:J.04 2005 1367182257127/datastreams/DS.002.0.01.ARTIC/content

Nograšek, J. (2011). Change management as a critical success factor in e-government implementation. Business Systems Research, 2(2). https://doi.org/10.2478/v10305-012-0016-y

Petrou, P., Demerouti, E., \& Schaufeli, W. B. (2018). Crafting the change: The role of employee job crafting behaviors for successful organizational change. Journal of Management, 44(5), 1766-1792. https://doi.org/10.1177/0149206315624961

Pollack, J., \& Pollack, R. (2015). Using Kotter's eight stage process to manage an organisational change program: Presentation and practice. Systemic Practice and Action Research, 28(1), 51-66. https://doi.org/10.1007/s11213-014-9317-0

Small, A., Gist, D., Souza, D., Dalton, J., Magny-Normilus, C., \& David, D. (2016). Using Kotter's change model for implementing bedside handoff. Journal of Nursing Care Quality, 31(4), 304-309. https://doi.org/10.1097/NCQ.0000000000000212

Tan, T., Gn, Y., \& Goh, S. (2019). ESRA19-0096 Implementing a regional anaesthesia (RA) time-out procedure (TO) in our hospital: Applying kotter's '8 step change management' (a management model). In E-Poster Viewing Abstracts (p. A177.2-A177). BMJ Publishing Group Ltd. https://doi.org/10.1136/rapm-2019-ESRAABS2019.286

Videikienė, S. ir Šimanskienė, L. (2013). Pokyčių valdymo sėkmės veiksniai organizacijose. Visuomenès saugumas ir viešoji tvarka, 10, 339-356. https://repository.mruni.eu/bitstream/handle/007/15120/Videikien .pdf?sequence=1

Videikiené, S. ir Šimanskienè, L. (2014). Pokyčių valdymo kliūtys organizacijose: teoriniai ir praktiniai aspektai. Management of Organizations: Systematic Research, 70, 107-120. https://doi.org/10.7220/MOSR.1392.1142.2014.70.8

Vienažindienè, M., \& Čiarnienè, R. (2007). The changes of public organizations human resources management: Theoretical aspect. Economics and Management, 12, 600.

Wentworth, D. K., Behson, S. J., \& Kelley, C. L. (2018). Implementing a new student evaluation of teaching system using the Kotter change model. Studies in Higher Education, 45(3), 511-523.

https://doi.org/10.1080/03075079.2018.1544234 


\section{Priedas. Anketinès apklausos klausimai}

1. Kaip suprantate organizacinius pokyčius? Pažymèkite vieną, Jūsų nuomone tiksliausią apibrèžimą.

$\square \quad$ Nuoseklus procesas, kuriam reikalingas detalus planavimas, aiškūs tikslai, atviras bendravimas ir nuolatinis dėmesys darbuotojų atsiliepimams.

$\square \quad$ Pakeitimai siekiant tobulinti ar iš esmès keisti organizacijoje vykstančius procesus.

$\square \quad$ Procesas, kuris įvyksta savaime bei nepriklauso nuo organizacijos pastangų tuos procesus ịgyvendinti

2. Ar teko vykdyti pokyčius organizacijoje? (Jeigu atsakymas „ne“ - praleiskite 3 - 5 klausimus)

$\square \quad$ Taip

$\square \quad \mathrm{Ne}$

3. Kokios, Jūsų nuomone, dažniausiai pasitaikančios kliūtys pokyčių valdyme.

$\square \quad$ Darbuotojų pasipriešinimas
$\square \quad$ Finansiniai sunkumai
$\square \quad$ Nenoras keisti darbo ịpročius
$\square \quad$ Baimė dèl nesėkmingų rezultatu
$\square \quad$ Komunikacijos stoka

4. Ar vykdant pokyčius organizacijoje teko susidurti su darbuotojų pasipriešinimu? (Jeigu atsakymas „ne“ praleiskite 5 klausimą).
$\square \quad$ Taip
$\square \quad \mathrm{Ne}$

5. Dèl kokių priežasčių, Jūsų nuomone, vyko darbuotojų pasipriešinimas?
Pokyčių nesupratimas
Nepasitikèjimas savo kompetencija
Baimè, kad bus daugiau darbo
Informacijos stygius

6. Ivvertinkite pateiktus veiksnius nuo 1 iki 5. Kurie iš jų, Jūsų nuomone, labiausiai lemia sèkmingą organizacinių pokyčių valdymą? (5 - labiausiai lemia, 1 - mažiausiai lemia)
Lyderio vaidmuo
Komunikacija
Vizijos ir strategijos iškèlimas
Komandinis darbas (darbuotojų įsitraukimas)
Smulkių rezultatų akcentavimas

2 Priedas. Ekspertų kompetencijos koeficiento skaičiavimas

\begin{tabular}{|c|c|c|c|c|c|}
\hline \multicolumn{7}{|c|}{ Veiksniai } \\
\hline Eksperto numeris & $\begin{array}{c}\text { Lyderio } \\
\text { vaidmuo }\end{array}$ & Komunikacija & $\begin{array}{c}\text { Vizijos ir strategijos } \\
\text { iškèlimas }\end{array}$ & $\begin{array}{c}\text { Komandinis } \\
\text { darbas }\end{array}$ & $\begin{array}{c}\text { Smulkiu rezultatu } \\
\text { akcentavimas }\end{array}$ \\
\hline$E 1$ & 5 & 2 & 1 & 3 & 4 \\
\hline$E 2$ & 2 & 4 & 1 & 3 & 5 \\
\hline$E 3$ & 2 & 3 & 1 & 4 & 5 \\
\hline$E 4$ & 5 & 3 & 1 & 4 & 2 \\
\hline$E 5$ & 5 & 3 & 2 & 1 & 4 \\
\hline Rangų suma & 19 & 15 & 6 & 15 & 20 \\
\hline Grupiniai i̇verčiai & 3,8 & 3,0 & 1,2 & 3,0 & 4,0 \\
\hline
\end{tabular}

\begin{tabular}{l|l} 
Ekspertų kof. & 0,2 \\
\hline
\end{tabular}




\begin{tabular}{|c|c|c|c|c|c|}
\hline Eksperto numeris & \multicolumn{5}{|c|}{ Lambdos apskaičiavimas } \\
\hline$E 1$ & 19,0 & 6,0 & 1,2 & 9,0 & 16,0 \\
\hline$E 2$ & 7,6 & 12,0 & 1,2 & 9,0 & 20,0 \\
\hline$E 3$ & 7,6 & 9,0 & 1,2 & 12,0 & 20,0 \\
\hline$E 4$ & 19,0 & 9,0 & 1,2 & 12,0 & 8,0 \\
\hline$E 5$ & 19,0 & 9,0 & 2,4 & 3,0 & 16,0 \\
\hline
\end{tabular}

Lambda

249,4

\begin{tabular}{|c|c|c|c|c|}
\hline & Suma & $\begin{array}{c}\text { Kompetencijos } \\
\text { kof. }\end{array}$ & Vidurkis & $\begin{array}{c}\text { Standartinis } \\
\text { nuokrypis }\end{array}$ \\
\hline$E 1$ & 51,2 & 0,205 & 0,200 & 0,003 \\
\hline$E 2$ & 49,8 & 0,200 & & \\
\cline { 1 - 2 }$E 3$ & 49,8 & 0,200 & & \\
\cline { 1 - 2 }$E 4$ & 49,2 & 0,197 & & \\
\cline { 1 - 2 }$E 5$ & 49,4 & 0,198 & & \\
\hline
\end{tabular}

\begin{tabular}{|l|l|}
\hline \multicolumn{2}{|c|}{ Intervalas } \\
\hline 0,194 & 0,206 \\
\hline
\end{tabular}

3 Priedas. Konkordancijos koeficiento skaičiavimas

\begin{tabular}{|c|c|c|c|c|c|}
\hline \multicolumn{7}{|c|}{ Rangai } \\
\hline Eksperto numeris & $\begin{array}{c}\text { Lyderio } \\
\text { vaidmuo }\end{array}$ & Komunikacija & $\begin{array}{c}\text { Vizijos ir strategijos } \\
\text { iškèlimas }\end{array}$ & $\begin{array}{c}\text { Komandinis } \\
\text { darbas }\end{array}$ & $\begin{array}{c}\text { Smulkių rezultatų } \\
\text { akcentavimas }\end{array}$ \\
\hline$E 1$ & 5 & 2 & 1 & 3 & 4 \\
\hline$E 2$ & 2 & 4 & 1 & 3 & 5 \\
\hline$E 3$ & 2 & 3 & 1 & 4 & 5 \\
\hline$E 4$ & 5 & 3 & 1 & 4 & 2 \\
\hline E5 & 5 & 3 & 2 & 1 & 4 \\
\hline Rangų suma & 19 & 15 & 15 & 15 & 20 \\
\hline Rangų sumų vidurkis & 15 & 15 & 81 & 0 & 15 \\
\hline Nuokrypio kvadratas & 16 & 0 & & & \\
\hline
\end{tabular}

\title{
SUCCESSFUL MANAGEMENT OF ORGANIZATIONAL CHANGE
}

\section{Karolina PETRAUSKAITE், Renata KORSAKIENE்}

\begin{abstract}
Organizations are constantly facing with changes and change management. There are many resistance factors involved change and also many changes fail because of bad change management. At this article examines organizational change concepts and change management models, identifies organizational change management success factors and performs a comparative analysis of approaches to successful change management. Based on this analysis, have made expert survey to identify the success factors within organizations. The research found that the most important factors for success are vision and strategy development, communication and teamwork.
\end{abstract}

Keywords: change, change management, organizational change, success factors, organizational change management, successful change management. 